\title{
Особливості проведення факторної терапії у дітей з гемофілією
}

\author{
К.В. Вільчевська \\ Національна дитяча спеціалізована лікарня «Охматдит», Київ, Україна \\ ДУ «Інститут невідкладної та відновної хірургії імені В.К. Гусака НАМН України», Київ, Україна
}

Згідно зі статистичними даними за 2017 р., на диспансерному обліку в Україні перебували $>2$ тис. пацієнтів з гемофілією та хворобою Віллебранда, 3 яких 27\% - діти. Тяжка форма гемофілії становить 60-70\% усіх випадків захворювання [1]. Більшість хворих на гемофілію - чоловіки, однак відомі поодинокі випадки гемофілії у жінок при спадкуванні гена водночас від батька, хворого на гемофілію, і матері - носія гена [2].

Клінічна картина гемофілії характеризується наявністю спонтанних, тривалих кровотеч, кровотеч у м'язи та суглоби і розвитком гемофілічної артропатії. При цьому навіть одна кровотеча може бути пов'язана з ризиком для пацієнта. Дані літератури свідчать, що при одноразовому внутрішньочерепному крововиливі ризик летального кінця становить 20\% [3]. Крововиливи у суглоби виникають значно частіше порівняно із внутрішньочерепними крововиливами та запускають каскад біологічних реакцій, які в подальшому можуть призвести до розвитку прогресуючої деструкції суглоба та в результаті - до деформуючої артропатії. Показано, що навіть незначна кровотеча у суглоб може викликати незворотні прогресуючі структурні зміни у ньому [4]. Згідно 3 результатами іншого дослідження, кількість суглобових кровотеч напряму пов'язана з ушкодженням суглобів. Так, на прикладі 15 пацієнтів із гемофілією продемонстровано, що $\geq 4$ гемартрозів за рік асоційовані з розвитком артропатії, що в подальшому призведе до інвалідизації пацієнта $[5,6]$. При цьому якість життя у пацієнтів із гемофілією, що не мають жодної кровотечі протягом року, практично відповідає якості життя здорових людей.

Питання ефективного лікування пацієнтів із гемофілією стоїть дуже гостро. Сьогодні основним методом лікування гемофілії $\epsilon$ застосування замісної терапії концентратами факторів згортання FVIII при гемофілії A та FIX — гемофілії B.

При менеджменті пацієнтів із гемофілією перед лікарем стоїть завдання зупинити кровотечу і запобігти їі рецидивам. Адекватна гемостатична терапія - основний метод лікування та профілактики геморагічних ускладнень у хворих на гемофілію, сучасна стратегія якої представлена:

- замісною факторною гемостатичною терапією;

- застосуванням препаратів із шунтуючим механізмом дії;

- нефакторною терапію (табл. 1).

Таблиця 1 Факторна та нефакторна терапія гемофілії

\begin{tabular}{|c|c|}
\hline \multicolumn{2}{|c|}{ Терапія гемофілії } \\
\hline Факторна & Нефакторна \\
\hline $\begin{array}{l}\text { Однофакторні концентрати: } \\
\text { • деривати плазми крові/рекомбінантні } \\
\text { • стандартні/3 подовженим періодом напіввиве- } \\
\text { дення }\end{array}$ & Еміцизумаб \\
\hline Концентрати, що містять >2 факторів згортання & Анти-TFPI \\
\hline $\begin{array}{l}\text { Шунтуючі препарати: } \\
\text { • rFVIIla } \\
\text { • aPCC }\end{array}$ & $\begin{array}{l}\text { Терапія, спрямована на антитромбін: } \\
\text { - антитіла } \\
\text { • аптамери } \\
\text { • технології РНК-інтерференції }\end{array}$ \\
\hline & $\begin{array}{l}\text { Генна терапія: } \\
\text { • пригнічення АРС } \\
\text { • рекомбінантний протромбін }\end{array}$ \\
\hline
\end{tabular}

rFVIIa — рекомбінантний активований FVII; TFPI — інгібітор шляху тканинного фактора; $\mathrm{APC}$ - комплекс, що стимулює анафазу; аРСС — антиінгібіторний коагуляційний комплекс.
Сучасна тактика лікування гемофілії представлена декількома підходами, які включають лікування «за вимогою» (екстрене лікування), лікування в домашніх умовах та профілактичне лікування. Кожен з підходів має свої особливості. Так, лікування «за вимогою» характеризується тим, що препарати вводять в умовах медичного закладу за фактом розвитку кровотечі. Лікування в домашніх умовах застосовується при нетяжких геморагічних кризах і становить введення фактора поза медичним закладом без спостереження медичного персоналу (лікування проводять члени родини хворого після навчання правилам введення препаратів). Профілактичне лікування характеризується тим, що препарати вводять «заздалегідь», з метою запобігання розвитку кровотеч. Відповідно до наявних даних, профілактична терапія $€$ основним напрямком терапії у пацієнтів віком <17 років, тоді як серед дорослого населення переважає терапія «за вимогою», хоча ми маємо прагнути до проведення профілактичної терапії усім хворим на гемофілію незалежно від віку.

До 1960-х років при лікуванні пацієнтів із гемофілією застосовували цільну кров або заморожену плазму крові. Після розроблення методу кріопреципітації у 1966 р. зареєстрований перший препарат FVIII, який отримували з плазми крові донорів, а потім - ліофілізований концентрат FVIII, що істотно спростило лікування пацієнтів із гемофілією А. Після впровадження діагностичних тестів на віруси гепатиту $C$ та імунодефіциту людини почали застосовувати вірусінактивований концентрат FVIII, а клонування гена FVIII ініціювало появу першого рекомбінантного FVIII. Сьогодні для профілактики та купірування кровотеч при гемофілії наявний великий вибір препаратів: плазмові, рекомбінантні, концентрати FVIII, rFVIIa і концентрати з тривалим періодом напіввиведення. В останні роки активно вивчають можливості застосування моноклональних антитіл і генних препаратів у лікуванні хворих на гемофілію.

Історія впровадження профілактичної терапії до клінічної практики лікування пацієнтів із тяжкою формою гемофілії починає свій відлік з 1976 р., коли у Швеції вперше був застосований цей підхід. Профілактична терапія ґрунтується на спостереженні, що хворі з середньотяжкою формою гемофілії з рівнем фактора згортання крові >1 МО/дл рідко відчувають спонтанні кровотечі і мають вищі шанси на збереження функції суглоба порівняно з пацієнтами з тяжкою формою гемофілії. Відповідно вченими висунута гіпотеза, що контроль рівня фактора крові в межах $>1 \%$ може бути ефективною стратегією лікування гемофілії. Ця концепція підтверджена низкою клінічних досліджень і з 1990 р. впроваджена, як терапія першої лінії дітей з тяжкою формою гемофілії, а з початку 2000-х років профілактичну терапію почали впроваджувати і для лікування дорослих пацієнтів [7, 8]. Сьогодні профілактична терапія $€$ загальновизнаним стандартом лікування дітей із тяжкою формою гемофілії [9].

Профілактична терапія дає можливість мінімізувати інвалідизацію пацієнтів з гемофілією або зовсім уникнути ії та дозволяє пацієнтам жити повноцінним життям. Сучасні рекомендації регламентують починати профілактичне лікування після першого гемартрозу у ранньому дитячому віці. При тяжкому перебігу захворювання рекомендують продовжувати лікування якомога довше, незалежно від віку пацієнта [10]. Сьогодні профілактична замісна терапія концентратами факторів згортання крові - необхідна умова збереження фізичного та психологічного здоров'я пацієнтів із тяжкою і середньотяжкою формою 
гемофілії. Існує чотири види профілактичної терапії: первинна, вторинна, третинна та періодична (табл. 2) [11]. Первинна профілактика характеризується регулярним введенням концентратів з метою профілактики кровотеч. Вторинна профілактика призначається пацієнтам з наявними ознаками ураження суглобів та спрямована на зниження прогресування гемофілічної артропатії. Результати проспективного відкритого рандомізованого дослідження SPINART продемонстрували, що у пацієнтів із тяжкою формою гемофілії А на фоні терапії рекомбінантним FVIII (rFVIII) спостерігали зменшення річної кількості гемартрозів на 93\% порівняно з лікуванням за потребою (рисунок) [9].

Таблиця 2 Види профілактичної терапії гемофілії

\begin{tabular}{|c|c|c|}
\hline \multicolumn{3}{|c|}{ Профілактична терапія гемофілії } \\
\hline Вид & Визначення & Мета \\
\hline Первинна & $\begin{array}{l}\text { Регулярне проведення замісної терапії. } \\
\text { Починається за відсутності ознак } \\
\text { пошкодження суглобів, до 2-річного віку і } \\
\text { хоча } 6 \text { до 2-го епізоду кровотечі }\end{array}$ & $\begin{array}{l}\text { Запобігання розвитку } \\
\text { артропатій або кровотеч, } \\
\text { що загрожують життю }\end{array}$ \\
\hline Вторинна & $\begin{array}{l}\text { Регулярне проведення замісної терапії. } \\
\text { Розпочинається після початкового } \\
\text { ушкодження суглоба чи серйозної } \\
\text { кровотечі. } \\
\text { Будь-яка профілактика, що почалася після } \\
\text { множинних кровотеч, повинна } \\
\text { розглядатися як вторинна }\end{array}$ & $\begin{array}{l}\text { Зниження частоти } \\
\text { кровотеч, ураження } \\
\text { суглобів-мішеней, } \\
\text { прогресування артропатій } \\
\text { та розвитку кровотеч, що } \\
\text { загрожують життю }\end{array}$ \\
\hline Третинна & $\begin{array}{l}\text { Регулярне проведення замісної терапії. } \\
\text { Починається в дорослому віці } \\
\text { для запобігання розвитку кровотеч, } \\
\text { що загрожують життю, та зменшення } \\
\text { прогресування вже наявної артропатії }\end{array}$ & $\begin{array}{l}\text { Призупинення клінічних } \\
\text { симптомів артропатії } \\
\text { та запобігання розвитку } \\
\text { інших ускладнень }\end{array}$ \\
\hline $\begin{array}{l}\text { Профілактика } \\
\text { з перервами } \\
\text { (періодична } \\
\text { профілактика) }\end{array}$ & $\begin{array}{l}\text { Введення концентратів факторів < } 45 \text { тиж } \\
\text { на рік }\end{array}$ & $\begin{array}{l}\text { Зниження частоти } \\
\text { кровотеч }\end{array}$ \\
\hline
\end{tabular}

Рисунок Зниження частоти гемартрозів на фоні вторинної профілактики

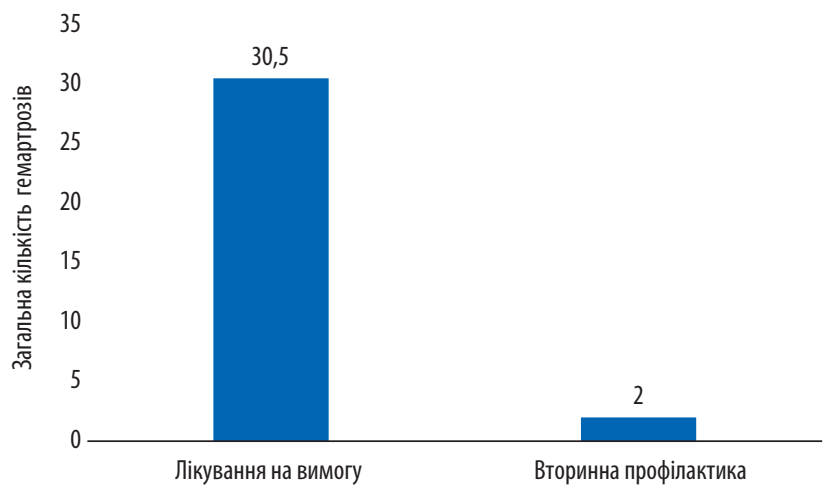

Профілактична терапія суттєво покращує довгостроковий клінічний прогноз порівняно з лікуванням «за вимогою». Так, дані літератури свідчать, що профілактична терапія значно знижує частоту кровотеч і виникнення артропатій, може знизити потребу в госпіталізації та ортопедичних хірургічних втручаннях, поліпшити якість життя пацієнтів [12]. Таким чином, Всесвітня ор-

Відомості про автора:

Вільчевська Катерина Вікторівна — кандидат медичних наук, завідувач Центру патології гемостазу Національної дитячої спеціалізованої лікарні «0хматдит», завідувач центру патології гемостазу ДУ «Інститут невідкладної та відновної хірургії імені В.К. Гусака НАМН України», Київ, Україна.

Адреса для кореспонденції:

Вільчевська Катерина Вікторівна

01135, м. Київ, вул. Шолуденка, 10

E-mail:dr.vilchevska@gmail.com ганізація охорони здоров'я, Всесвітня федерація гемофілії (World Federation of Hemophilia - WFH) та національні організації багатьох країн схвалили призначення ранньої профілактичної терапії як стандарт лікування дітей з тяжкою формою гемофілії та рекомендують продовження профілактичної терапії у дорослому віці [13].

Сьогодні в системі охорони здоров'я все більш актуальними стають питання персоніфікації терапії та лікування гемофілії не $\epsilon$ винятком. Так, міжнародні товариства зазначають на важливості індивідуалізованого підходу до профілактичного лікування пацієнтів із гемофілією. Цей підхід базується на таких критеріях/ принципах менеджменту, як індивідуальний фармакокінетичний профіль, маса тіла, фенотип кровотечі, рівень фізичної активності, ураження суглобів та прихильність до лікування. Персоніфікований підхід до терапії сприяє підвищенню прихильності пацієнта до лікування, дозволить контролювати фармакокінетичні параметри, а також проводити обґрунтовану корекцію терапії. Таким чином, профілактична терапія не лише значно знижує частоту кровотеч і запобігає настанню артропатій порівняно з лікуванням «за вимогою», але й підвищує якість життя і покращує соціалізацію пацієнтів.

За підтримки ТОВ «Такеда Україна» VV-MEDMAT-37244

\section{Список використаної літератури/References:}

1. IFAK (2018) Hemophilia. Situational analysis of problems in Ukraine.

2. Srivastava A., Brewer A.K., Mauser-Bunschoten E.P. et al. (2013) Guidelines for the management of hemophilia (WFH). Haemophilia, 19: e1-e47.DOI: 10.1111/j.1365-2516.2012.02909.x

3. Witmer C., Presley R., Kulkarni R. etal. (2011) Associations between intracranial haemorrhage and prescribed prophylaxis in a large cohort of haemophilia patients in the United States. Br. J. Haematol., 152(2): 211-216. doi: 10.1111/j.1365-2141.2010.08469.x

4. Gringeri A., Ewenstein B., Reininger A. (2014) The burden of bleeding in haemophilia: is one bleed too many? Haemophilia, 20(4): 459-463. doi: 10.1111/hae.12375

5. Carcao M., Srivastava A. (2016) FactorVIII/factor IX prophylaxis for severe hemophilia. Semin. Hematol., 53(1): 3-9. doi: 10.1053/j.seminhematol.2015.10.006

6. Funk M.B., Schmidt H., Becker S. et al. (2002) Modified magnetic resonance imaging score compared with orthopaedic and radiological scores for evaluation of haemophilic arthropathy. Haemophilia, 8(2): 98-103. D0I: 10.1046/j.1365-2516.2002.00585.x.

7. Nilsson I.M., Hedner U., Ahlberg A. (1976) Haemophilia prophylaxis in Sweden. Acta Paediatr., 65(2): 129-135. https://doi.org/10.1111/j.1651-2227.1976.tb16525.x

8. Rodriguez N.I., Hoots W.K. (2010) Advances in hemophilia: experimental aspects and therapy. Hematol. Oncol. Clin. North Am., 24(1): 181-198. doi: 10.1016/j.hoc.2009.11.003

9. Manco-Johnson M.J., Abshire T.C.,S Shapiro A.D. et al. (2007) Prophylaxis versus episodic treatment to prevent joint disease in boys with severe hemophilia. N. Engl. J. Med., 357(6): 535-544. doi: 10.1056/NEJMoa067659

10. Berntorp E., Astermark J., Björkman S. et al. (2003) Consensus perspectives on prophylactic therapy for haemophilia: summary statement. Haemophilia, 9(Suppl. 1): 1-4. doi: 10.1046/j.1365-2516.9.51.17.x

11. Fischer K., van der Bom J.G., Mauser-Bunschoten E.P. et al. (2002) The effects of postponing prophylactic treatment on long-term outcome in patients with severe hemophilia. Blood, 99(7):2337-2341. doi: 10.1182/blood.v99.7.2337

12. Oldenburg J. (2015) Optimal treatment strategies for hemophilia: achievements and limitations of current prophylactic regimens. Blood, 125(13): 2038-2044. doi: 10.1182/ blood-2015-01-528414

13. Srivastava A., Santagostino E., Dougall A. et al. (2020) WFH Guidelines for the Management of Hemophilia, $3^{\text {rd }}$ ed.

\section{Information about the author:}

Vilchevska Kateryna V. — Candidate of Medical Sciences, Head of the Center of hemostasis pathology of the National Children Special Hospital «Ohmatdet», Head of the Center of hemostasis pathology of the V.K. Gusak Institute of Urgent and Recovery Surgery of NAMS of Ukraine, Kyiv, Ukraine.

Address for correspondence:

Kateryna Vilchevska

01135, Kyiv, Sholudenko str., 10

E-mail: dr.vilchevska@gmail.com 
ТЕСТОВІ ЗАПИТАННЯ

(один або декілька правильних варіантів відповідей на кожне запитання)

1. Ступінь тяжкості порушень згортання крові та клінічних проявів при гемофілії А залежить від:
$\square$ рівня активності фактора FVIII у крові
$\square$ ступеня ураження суглобів
$\square$ частоти внутрішньочерепних крововиливів
усі відповіді правильні

2. Основним методом лікування гемофілії $\epsilon$ :
$\square$ замісна терапія концентратами факторів згортання крові
$\square$ індукція імунної толерантності
$\square$ застосування глюкокортикостероїдів
$\square$ переливання крові

3. Визначте ключові типи терапії гемофілії:
$\square$ лікування «за вимогою»
$\square$ стаціонарне лікування
$\square$ профілактичне лікування
індукція імунної толерантності

4. Основним типом терапії у пацієнтів із гемофілією має бути:

$\square$ профілактична терапія

$\square$ екстрена терапія

$\square$ переливання крові

$\square$ усі відповіді правильні

5. Недоліки терапії дорослих пацієнтів із гемофілією в Україні: переважання терапії «за вимогою» $\square$ практична відсутність застосування профілактичної терапії

$\square$ неурегульоване питання «домашнього» лікування

$\square$ усі відповіді правильні

6. Первинна профілактика спрямована на:

$\square$ запобігання розвитку артропатій або кровотеч, що загрожують життю

$\square$ зниження частоти кровотеч

$\square$ зменшення ураження суглобів-мішеней

$\square$ призупинення клінічних симптомів артропатії

7. Вторинна профілактика спрямована на:

$\square$ зниження частоти кровотеч та ураження суглобів-мішеней

$\square$ запобігання розвитку артропатій або кровотеч, що загрожують життю

$\square$ зниження частоти кровотеч

$\square$ зменшення ураження суглобів-мішеней

8. Індивідуалізований підхід до профілактичного лікування пацієнтів із гемофілією базується на:

$\square$ індивідуальному фармакокінетичному профілю паці$\epsilon$ нта

$\square$ індивідуальному фармакодинамічному профілю паці$\epsilon$ нтта

$\square$ масі тіла

$\square$ рівні фізичної активності
Для отримання сертифіката дайте відповідь на тестові запитання в режимі on-line на сайті журналу www.umj.com.ua або надішліть ксерокопію сторінок з відповідями разом з контактною інформацією за адресою:

01001, Київ-1, a/c «B»-82, ТОВ «МОРІОН»
ПІБ

Поштова адреса: індекс
область
район
місто
вулиця
будинок
квартира
Телефон
E-mail

